\title{
'Royal Gala' apple quality stored under ultralow oxygen concentration and low temperature conditions
}

\author{
Anderson Weber ${ }^{(1)}$, Auri Brackmann ${ }^{(1)}$, Rogério de Olivera Anese ${ }^{(1)}$, Vanderlei Both ${ }^{(1)}$ \\ and Elizandra Pivotto Pavanello(1) \\ (1)Universidade Federal de Santa Maria, Departamento de Fitotecnia, Prédio 77, Cidade Universitária, Bairro Camobi, \\ CEP 97105-900 Santa Maria, RS, Brazil. E-mail: anweba@yahoo.com.br, auribrackmann@gmail.com, rogerio_anese@yahoo.com.br, \\ vanderleiboth@yahoo.com.br, elizandra_pavanello@yahoo.com.br
}

\begin{abstract}
The objective of this work was to evaluate the interaction of ultralow oxygen concentrations (ULO) with storage temperatures and carbon dioxide partial pressures and its influence on fruit quality preservation and on the occurrence of physiological disorders in 'Royal Gala' apples. The experiment was carried out in a completely randomized design, with four replicates 25 -fruit. ULO conditions $\left(1.0 \mathrm{kPa} \mathrm{O}_{2}+2.0 \mathrm{kPa} \mathrm{CO}\right.$; $0.8 \mathrm{kPa} \mathrm{O}_{2}+1.5 \mathrm{kPaCO}_{2} ; 0.8 \mathrm{kPa} \mathrm{O}_{2}+1.0 \mathrm{kPaCO} ; 0.6 \mathrm{kPa} \mathrm{O}_{2}+1.5 \mathrm{kPa} \mathrm{CO}_{2} ;$ and $0.6 \mathrm{kPa} \mathrm{O}_{2}+1.0 \mathrm{kPa} \mathrm{CO}_{2}$ ) were tested at $0,0.5$ and $1.0^{\circ} \mathrm{C}$, in a $5 \times 3$ factorial arrangement. Fruit quality and ripening analyses were performed after eight-month storage plus seven days of shelf-life at $20^{\circ} \mathrm{C}$. Oxygen partial pressures below $0.8 \mathrm{kPa}$ increased the occurrence of internal breakdown and mealiness. The best ULO condition was $1.0 \mathrm{kPa}$ $\mathrm{O}_{2}+$ plus $2.0 \mathrm{kPa} \mathrm{CO}_{2}$ at $1.0^{\circ} \mathrm{C}$. The interaction of ULO conditions and storage temperatures shows the need of increasing $\mathrm{O}_{2}$ partial pressure at higher storage temperatures.
\end{abstract}

Index terms: Malus domestica, carbon dioxide, controlled atmosphere, decay, physiological disorders.

\section{Qualidade de maçã 'Royal Gala' armazenada em condições de concentração ultrabaixa de oxigênio e baixa temperatura}

Resumo - O objetivo deste trabalho foi avaliar a interação de concentrações ultrabaixas de oxigênio (ULO) com diferentes temperaturas e pressões parciais de gás carbônico sobre a conservação da qualidade e a ocorrência de distúrbios fisiológicos em maçãs 'Royal Gala'. O experimento foi realizado em delineamento inteiramente casualizado, com quatro repetições de 25 frutos. As concentrações ULO $\left(1,0 \mathrm{kPa} \mathrm{O}_{2}+2,0 \mathrm{kPa} \mathrm{CO}, 0,8 \mathrm{kPa}\right.$ $\mathrm{O}_{2}+1,5 \mathrm{kPa} \mathrm{CO}, 0,8 \mathrm{kPa} \mathrm{O}_{2}+1,0 \mathrm{kPa} \mathrm{CO}, 0,6 \mathrm{kPa} \mathrm{O}+1,5 \mathrm{kPa} \mathrm{CO}_{2}$ e $0,6 \mathrm{kPa} \mathrm{O}+1,0 \mathrm{kPa} \mathrm{CO}_{2}$ ) foram avaliadas a $0,0,0,5 \mathrm{e} 1,0^{\circ} \mathrm{C}$, em arranjo fatorial de $5 \times 3$. As análises da qualidade e amadurecimento dos frutos foram realizadas após oito meses de armazenamento e mais sete dias de exposição a $20^{\circ} \mathrm{C}$. As pressões parciais de $\mathrm{O}_{2}$ abaixo de $0,8 \mathrm{kPa}$ aumentaram a ocorrência de degenerescência de polpa e polpa farinácea. A melhor condição de ULO foi a de $1,0 \mathrm{kPa} \mathrm{O}_{2}+2,0 \mathrm{kPa} \mathrm{CO}_{2}$ a $1,0^{\circ} \mathrm{C}$. A interação entre condições de ULO e temperaturas de armazenamento evidencia necessidade de aumento das pressões parciais de $\mathrm{O}_{2}$ quando a temperatura de armazenamento é mais elevada.

Termos para indexação: Malus domestica, gás carbônico, atmosfera controlada, podridões, distúrbios fisiológicos.

\section{Introduction}

Controlled-atmosphere storage extend the postharvest life of apple fruit. The system combines low temperatures with low partial pressures of $\mathrm{O}_{2}$ and high partial pressure of $\mathrm{CO}_{2}$, which reduce respiration rates, ethylene $\left(\mathrm{C}_{2} \mathrm{H}_{4}\right)$ biosynthesis and action (Yang \& Hoffman, 1984), thereby maintaining the physical and chemical properties of fruit. However, there are still significant postharvest losses of fruit due to pathogens and physiological disorders, which may reach up to $60 \%$ depending on the year (Brackmann et al., 2002). Therefore, it has become necessary to improve the currently used storage techniques to reduce fruit loss.

Partial pressures of $\mathrm{O}_{2}$ and $\mathrm{CO}_{2}$ recommended for the storage of 'Royal Gala' apples in Brazil are 1.0 and $2.5 \mathrm{kPa}$, respectively (Brackmann et al., 2008). It is well documented that low levels of $\mathrm{O}_{2}$ in controlled-atmosphere storage reduce fruit respiration and ethylene production and action. Generally, the lower the metabolic rates, the longer the postharvest life and quality of apples. Therefore, studies have been conducted to define the use of ultralow oxygen

Pesq. agropec. bras., Brasília, v.46, n.12, p.1597-1602, dez. 2011 
partial pressures (Zanella, 2003), to suppress fruit metabolism, and to obtain higher fruit quality by reducing losses.

Under controlled-atmosphere storage, the oxygen partial pressure cannot fall below the minimum limit needed for aerobic energy production. Below this minimum limit, also known as the anaerobic compensation point, the anaerobic respiration becomes the major energy production pathway (Saquet \& Streif, 2008). This change in metabolism may cause the accumulation of volatile substances, like ethanol and acetaldehyde, and may ultimately result in the development of physiological disorders such as flesh breakdown (Pedreschi et al., 2009). The lowest oxygen limit may vary among fruit of the same species (Prange et al., 2003), depending on the region, the year of production (Delong et al., 2004), and on the storage temperature (Wright et al., 2010). Therefore, ultralow oxygen must be studied before it is applied commercially for 'Royal Gala' apples.

The lower oxygen limits recommended for the 'Delicious', 'Law Rome' and 'McIntosh' apples are $0.7 \mathrm{kPa}, 0.9 \mathrm{kPa}$ and $1.9 \mathrm{kPa}$, respectively (Gran \& Beaudry, 1993). 'Granny Smith' apples stored under $\mathrm{O}_{2}$ partial pressures of $0.7 \mathrm{kPa}$, from four to six months, showed a ground color identical to the one they had at harvest time, according to Zanella (2003), who also reported a lower occurrence of flesh breakdown, better retention of flesh firmness and total absence of scald in apples stored under ultralow oxygen conditions. For apples cultivated in Brazil, Brackmann et al. (2000) reported that the optimum storage conditions for 'Gala' apples were 0.75 to $1.0 \mathrm{kPaO}_{2}$, at $1.0^{\circ} \mathrm{C}$. However, Ceretta et al. (2010) reported, for the same cultivar stored at $0^{\circ} \mathrm{C}$ and $\leq 0.8 \mathrm{kPa} \mathrm{O}_{2}$ conditions, an increase of skin cracking occurrences, internal breakdown and decay compared to fruit stored under $1.0 \mathrm{kPa} \mathrm{O}$. Discrepancy between these reports is probably due to the distinct temperatures employed in each study, which shows that there might be a relationship between storage temperature and $\mathrm{O}_{2}$ levels in the prolonged maintenance of apple quality.

The objective of this work was to evaluate the interaction of ultralow oxygen partial pressure with different temperatures and carbon dioxide partial pressures and its influence on fruit quality preservation and on the occurrence of physiological disorders in 'Royal Gala' apples.

\section{Materials and Methods}

The experiment was carried out at the Núcleo de Pesquisa em Pós-colheita, Departamento de Fitotecnia, Universidade Federal de Santa Maria, Santa Maria, RS, Brazil, in 2008. Fruit samples were harvested in a commercial orchard, in Vacaria county, RS, Brazil. At harvest, fruit showed 6.70 starch index (scale 0, minimum; 10, maximum starch hydrolysis), 92.8 $\mathrm{N}$ flesh firmness, and $21.8 \eta \mathrm{L} \mathrm{g}^{-1} \mathrm{~h}^{-1}$ $\mathrm{C}_{2} \mathrm{H}_{4}$ 1-aminocyclopropane-1-carboxylic acid (ACC) oxidase activity, and produced $1.33 \mu \mathrm{L} \mathrm{kg}^{-1} \mathrm{~h}^{-1} \mathrm{C}_{2} \mathrm{H}_{4}$ and $6.86 \mathrm{~mL} \mathrm{~kg}^{-1} \mathrm{~h}^{-1} \mathrm{CO}_{2}$ (respiration rate).

The experiment was conducted in a completely randomized design, with four replicates of 25 fruit. Five ultralow oxygen conditions were tested at three different temperatures, in a factorial arrangement $(5 \times 3)$. The controlled-atmosphere storage conditions were: $1.0 \mathrm{kPa} \mathrm{O}+2.0 \mathrm{kPaCO} ; 0.8 \mathrm{kPa} \mathrm{O}_{2}+1.5 \mathrm{kPa}$ $\mathrm{CO}_{2} ; 0.8 \mathrm{kPa} \mathrm{O}+1.0 \mathrm{kPa} \mathrm{CO} ; 0.6 \mathrm{kPa} \mathrm{O}+1.5 \mathrm{kPa}$ $\mathrm{CO}_{2}$ and $0.6 \mathrm{kPa} \mathrm{O}_{2}+1.0 \mathrm{kPa} \mathrm{CO}_{2}$. All these conditions were tested at $0,0.5$ and $1.0^{\circ} \mathrm{C}$.

The fruit were stored in hermetically sealed experimental chambers with $0.232 \mathrm{~m}^{3}$, which were placed inside a cold storage room with $48 \mathrm{~m}^{3}$ each, at $0,0.5$ and $1.0^{\circ} \mathrm{C}$ (oscillation of $\pm 0.1^{\circ} \mathrm{C}$ ). The relative humidity inside the chambers was maintained at $96 \pm 1 \%$. Temperature was controlled by thermostats and checked daily by bulb mercury thermometers with a $0.1^{\circ} \mathrm{C}$ resolution inserted in the fruit flesh. The dilution of $\mathrm{O}_{2}$ in the storage chamber was done with injections of $\mathrm{N}_{2}$ obtained from a pressure swing adsorption (PSA) nitrogen generator (Janus \& Pergher, Porto Alegre, RS, Brazil). Partial pressures of $\mathrm{CO}_{2}$ were obtained by gas injection from a high pressure cylinder. The desired partial pressures were maintained by automatic gas control equipment (Kronenberger/Climasul, Caxias do Sul, RS, Brazil). The $\mathrm{O}_{2}$ consumed by respiration was replaced by injections of atmospheric air into the chambers, and excessive $\mathrm{CO}_{2}$ produced by respiration was absorbed by a $40 \%$ potassium hydroxide solution.

Fruit quality and ripening parameters were evaluated after eight-month storage, plus seven days of shelf-life at $20^{\circ} \mathrm{C}$, except for respiration, which was assessed at the removal from the storage chambers and after the six days of air-exposure at $20^{\circ} \mathrm{C}$. The parameters decay occurrence, flesh firmness, mealiness, internal breakdown, ACC oxidase activity, ethylene production 
rate and respiration rate were assessed and detailed as follows.

Decay occurrence was evaluated by counting fruit showing typical fungal lesions larger than $5 \mathrm{~mm}$ in diameter.

Flesh firmness was determined with a penetrometer model FT 327 (Effegi Systems, Milan, Italy), equipped with a $11 \mathrm{~mm}$ probe and measured in both sides of fruit equatorial region, from which the skin had been previously removed.

Mealiness was determined by visual quantification of fruit exhibiting symptoms related to this physiological disorder (dry and non-juicy flesh).

Internal breakdown was measured by visual evaluation of flesh browning, after transversal cuts across fruit.

ACC oxidase activity was determined in $3 \mathrm{~g}$ skin samples extracted from fruit equatorial region, from each experimental unit; these samples were immediately dipped into a solution containing $0.1 \mathrm{~mol} \mathrm{~L}^{-1} \mathrm{ACC}$ and $10 \mathrm{mmol} \mathrm{L}^{-1}$ MES buffer [2-(N-morpholino) ethanesulfonic acid] at $\mathrm{pH}$ 6.0; after $30 \mathrm{~min}$, samples were transferred to hermetic $50 \mathrm{~mL}$ syringes, to which $1 \mathrm{~mL} \mathrm{CO} 2$ was added. The ethylene concentration in the syringes was measured by gas chromatography after $30 \mathrm{~min}$, and the results were expressed as $\eta \mathrm{L} \mathrm{g}{ }^{-1} \mathrm{~h}^{-1} \mathrm{C}_{2} \mathrm{H}_{4}$ (Bufler, 1986). To analyze ethylene concentration, two gas samples of $1 \mathrm{~mL}$ extracted from the headspace of each syringes were injected in a gas cromatograph, Varian Gas Cromatograph Star CX 3400 model, (Varian, Palo Alto, CA, USA), equipped with a flame ionization detector (FID) and a Porapak N80/100 steel column. The column, injector and detector temperatures were 90,140 and $200^{\circ} \mathrm{C}$, respectively.

Ethylene production rate was determined by the use of approximately $1,200 \mathrm{~g}$ fruit which were placed into containers with $5,000 \mathrm{~mL}$ volume. These containers were hermetically sealed for approximately two hours. Ethylene synthesis, expressed as $\mu \mathrm{L} \mathrm{kg}^{-1} \mathrm{~h}^{-1} \mathrm{C}_{2} \mathrm{H}_{4}$, measured by gas chromatography, was calculated by taking into account the ethylene concentration, the mass of fruit, the free space inside the container, and time.

Respiration rate was determined by the volume of $\mathrm{CO}_{2}$ production. The air from the same container, used to determine the production of ethylene, was circulated through an electronic $\mathrm{CO}_{2}$ analyzer, with the infrared gas analyzer (IRGA) system (Agri-datalog, Lana, BZ,
Italy). Based on $\mathrm{CO}_{2}$ concentration, free space inside the container, fruit weight and closure time, the respiration rate was calculated and expressed as $\mathrm{mL} \mathrm{kg}^{-1} \mathrm{~h}^{-1} \mathrm{CO}_{2}$.

Before the analysis of variance, the results were tested for normality and homogeneity of errors by the Lilliefors and Bartlett tests, respectively. The parameters that fell outside the normality of errors were transformed by the formula arc sen square root $(x+0.5) / 100$, while the parameters with heteroscedasticity errors were transformed by the formula $\log _{10}(\mathrm{x}+1.0)$ to be returned to the group and then submitted to ANOVA tests. Average values were compared by Tukey's test, at $5 \%$ probability.

\section{Results and Discussion}

Fruit stored under $0.8 \mathrm{kPa} \mathrm{O}_{2}+1.5 \mathrm{kPa} \mathrm{CO}_{2}$ conditions and exposed for seven days at $20^{\circ} \mathrm{C}$ showed the lowest occurrence of decay, independently of the storage temperature (Table1). Low $\mathrm{O}_{2}$ partial pressures during the storage reduced the occurrence of decay during the post-storage period, possibly due to the fungistatic effect of low $\mathrm{O}_{2}$ concentration (Neuwald, 2004). Cellular energy production was likely induced by anaerobic respiration under $0.6 \mathrm{kPa}$ $\mathrm{O}_{2}$. As a result, cells were damaged, probably due to accumulation of fermentation products, and became sensitive to infections (Kader, 2002). Ceretta et al. (2010) also reported a higher decay occurrence in 'Gala' apples stored at $\mathrm{O}_{2}$ partial pressures below $0.8 \mathrm{kPa}$. This partial pressure of $\mathrm{O}_{2}(0.8 \mathrm{kPa})$ also increased decay susceptibility in 'Fuji' apples (Brackmann et al., 2001).

Flesh firmness was not significantly affected by the different ultralow oxygen and $\mathrm{CO}_{2}$ conditions (Table1). Storage temperatures of 0.5 and $1.0^{\circ} \mathrm{C}$ kept higher flesh firmness, in comparison to $0^{\circ} \mathrm{C}$. Brackmann et al. (2008) reported that 'Royal Gala' and 'Galaxy' apples showed greater flesh firmness at $0.5^{\circ} \mathrm{C}$ in comparison to $-0.5^{\circ} \mathrm{C}$. The loss of flesh firmness is usually linked to rates of respiration and ethylene production (Hiwasa, et al., 2003). In the present study, it was observed that after a six-day exposure to air at $20^{\circ} \mathrm{C}$, fruit stored at $0^{\circ} \mathrm{C}$ showed higher rates of respiration and ethylene production than fruit stored at 0.5 and $1.0^{\circ} \mathrm{C}$ (Table 2). It has been reported that increased ethylene synthesis induces the expression and the activity of cell-wall degrading enzymes (Prasanna et al., 2007) resulting in loss of firmness. 
The occurrence of mealiness had no interaction with ultralow oxygen conditions and temperatures (Table1). There was a lower occurrence of this disorder at $1.0^{\circ} \mathrm{C}$ storage temperature. However, the storage of apples at $0.8 \mathrm{kPa} \mathrm{O}_{2}$ with 2.0 or $1.5 \mathrm{kPa} \mathrm{CO}_{2}$ resulted in a higher occurrence of mealiness. This physiological disorder is associated with ripening, when protopectin degradation is enhanced (Prasanna et al., 2007), reducing the cell-to-cell adhesion and, ultimately, leading to the development of a mealy aspect. The activity of cell-wall degrading enzymes is highly correlated with ethylene biosynthesis and respiration rate (Wei et al., 2010).

There was a significant interaction between storage temperatures and ultralow oxygen conditions for flesh breakdown (Table 1). The temperature increase from 0 to $1.0^{\circ} \mathrm{C}$ decreased the occurrence of this disorder, especially in higher $\mathrm{O}_{2}$ partial pressure. According to Streif et al. (2003), many postharvest factors affect the occurrence of flesh breakdown in apples, such as harvest date, time between harvest and cooling, $\mathrm{CO}_{2}$ and $\mathrm{O}_{2}$ partial pressures, and storage interval and storage temperature. Flesh breakdown occurrence was lower at $1.0^{\circ} \mathrm{C}$ with the highest $\mathrm{O}_{2}$ levels $(0.8$ and
$1.0 \mathrm{kPa} \mathrm{O}$ associated with $2.0 \mathrm{kPa} \mathrm{CO}_{2}$ ). However, no statistic difference in the treatment $0.8 \mathrm{kPa} \mathrm{O}_{2}+$ $1.5 \mathrm{kPa} \mathrm{CO} 2$ was observed. At $0^{\circ} \mathrm{C}$ there was a lower occurrence of the disorder in conditions with a lower $\mathrm{O}_{2}$ level of $(0.6 \mathrm{kPa} \mathrm{O}+1.0 \mathrm{kPa} \mathrm{CO})$, although not differing from the conditions with 0.6 and $0.8 \mathrm{kPa} \mathrm{O}_{2}$ associated to $1.5 \mathrm{kPa} \mathrm{CO}$. The interaction between temperature and oxygen partial pressure resulted in the need to increasing $\mathrm{O}_{2}$ partial pressures as temperature was increased from 0 to $1.0^{\circ} \mathrm{C}$. A possible explanation to this result would be that the solubility of $\mathrm{O}_{2}$ inside the apple flesh decreases as the temperature rises (Yearsley et al., 1997). Consequently, if a lower solubility limits the $\mathrm{O}_{2}$ availability, it is expected that the minimum oxygen limit increases as a function of storage temperature rise. Similar results were reported by Wright et al. (2010) for 'Honeycrisp' apple. Thus, a higher occurrence of this disorder occurs probably due to a higher anaerobic respiration observed in fruit submitted to lower $\mathrm{O}_{2}$ partial pressure. The final products of this reaction, namely ethanol and acetaldehyde, and the imbalance between oxidative and reductive processes cause an energetic collapse

Table 1. Occurrence of decay, flesh firmness, mealiness and flesh breakdown in 'Royal Gala' apples, after eight months of storage at different conditions of controlled-atmosphere and temperature and an added exposition for seven days at $20^{\circ} \mathrm{C}^{(1)}$.

\begin{tabular}{|c|c|c|c|c|c|c|c|c|c|c|c|c|c|c|c|c|}
\hline \multirow{2}{*}{$\begin{array}{l}\mathrm{O}_{2}+\mathrm{CO}_{2} \\
(\mathrm{kPa})\end{array}$} & \multicolumn{3}{|c|}{ Decay (\%) } & \multirow[t]{2}{*}{ Mean } & \multicolumn{3}{|c|}{ Flesh firmness (N) } & \multirow[t]{2}{*}{ Mean } & \multicolumn{3}{|c|}{ Mealiness (\%) } & \multirow[t]{2}{*}{ Mean } & \multicolumn{3}{|c|}{ Flesh breakdown (\%) } & \multirow[t]{2}{*}{ Mean } \\
\hline & $0^{\circ} \mathrm{C}$ & $0.5^{\circ} \mathrm{C}$ & $1.0^{\circ} \mathrm{C}$ & & $0^{\circ} \mathrm{C}$ & $0.5^{\circ} \mathrm{C}$ & $1.0^{\circ} \mathrm{C}$ & & $0^{\circ} \mathrm{C}$ & $0.5^{\circ} \mathrm{C}$ & $1.0^{\circ} \mathrm{C}$ & & $0^{\circ} \mathrm{C}$ & $0.5^{\circ} \mathrm{C}$ & $1.0^{\circ} \mathrm{C}$ & \\
\hline Initial analysis ${ }^{(2)}$ & & 0.0 & & & & 92.8 & & & & 0.0 & & & & 0.0 & & \\
\hline $1.0+2.0$ & 14.0 & 8.8 & 7.5 & $10.1 \mathrm{ab}$ & $76.6 \mathrm{aA}$ & $75.4 \mathrm{aA}$ & $76.4 \mathrm{aA}$ & 76.2 & 26.7 & 30.3 & 16.3 & $24.4 b$ & $32.9 \mathrm{aA}$ & 17.7abB & $5.0 \mathrm{cC}$ & 18.5 \\
\hline $0.8+2.0$ & 10.0 & 12.7 & 7.6 & $10.1 \mathrm{ab}$ & $70.5 \mathrm{bB}$ & $77.5 \mathrm{aA}$ & $77.5 \mathrm{aA}$ & 75.2 & 42.5 & 38.0 & 17.8 & $32.8 \mathrm{a}$ & $36.3 \mathrm{aA}$ & $17.8 \mathrm{abB}$ & $8.9 \mathrm{cC}$ & 21.0 \\
\hline $0.8+1.5$ & 7.6 & 8.9 & 6.3 & $7.6 \mathrm{~b}$ & $73.2 \mathrm{abB}$ & $79.3 \mathrm{aA}$ & $75.8 \mathrm{aAB}$ & 76.1 & 34.1 & 29.1 & 20.3 & $27.9 \mathrm{ab}$ & $29.0 \mathrm{abA}$ & $13.9 \mathrm{bB}$ & $10.1 \mathrm{bcB}$ & 17.7 \\
\hline $0.6+1.5$ & 10.5 & 14.3 & 16.4 & $13.7 \mathrm{a}$ & $75.1 \mathrm{aA}$ & $77.7 \mathrm{aA}$ & $77.3 \mathrm{aA}$ & 76.7 & 28.6 & 29.4 & 11.4 & $23.2 b$ & $27.2 \mathrm{abA}$ & $14.0 \mathrm{bAB}$ & 19.1abB & 20.1 \\
\hline $0.6+1.0$ & 8.7 & 12.5 & 11.4 & $10.9 \mathrm{ab}$ & 73.5abA & $76.3 \mathrm{aA}$ & $76.8 \mathrm{aA}$ & 75.5 & 27.5 & 32.5 & 17.8 & $25.9 \mathrm{~b}$ & $25.0 \mathrm{bA}$ & $27.5 \mathrm{aA}$ & $22.8 \mathrm{aA}$ & 25.1 \\
\hline Mean & $10.2 \mathrm{~A}$ & $11.4 \mathrm{~A}$ & $9.8 \mathrm{~A}$ & - & 73.8 & 77.2 & 76.8 & - & $31.9 \mathrm{~A}$ & $31.9 \mathrm{~A}$ & $16.7 \mathrm{~B}$ & - & 30.1 & 18.2 & 13.2 & - \\
\hline
\end{tabular}

${ }^{(1)}$ Means followed by equal letters, lowercase in the columns and uppercase in the lines, do not differ by Tukey's test, at $5 \%$ probability. ${ }^{(2)}$ Initial analysis took place before fruit storage.

Table 2. ACC oxidase activity $\left(\eta \mathrm{L} \mathrm{g} \mathrm{g}^{-1} \mathrm{~h}^{-1} \mathrm{C}_{2} \mathrm{H}_{4}\right)$, ethylene production $\left(\mu \mathrm{L} \mathrm{kg}^{-1} \mathrm{~h}^{-1} \mathrm{C}_{2} \mathrm{H}_{4}\right)$ and respiration rate $\left(\mathrm{mL} \mathrm{kg}^{-1} \mathrm{~h}^{-1} \mathrm{CO}_{2}\right)$ of 'Royal Gala' apples, after eight months at different conditions of controlled-atmosphere and temperature ${ }^{(1)}$.

\begin{tabular}{|c|c|c|c|c|c|c|c|c|c|c|c|c|c|c|c|c|}
\hline \multirow{2}{*}{$\begin{array}{l}\mathrm{O}_{2}+\mathrm{CO}_{2} \\
(\mathrm{kPa})\end{array}$} & \multicolumn{3}{|c|}{ ACC oxidase activity } & \multirow[t]{2}{*}{ Mean } & \multicolumn{3}{|c|}{ Ethylene production rate } & \multirow[t]{2}{*}{ Mean } & \multicolumn{3}{|c|}{ Respiration rate chamber opening } & \multirow[t]{2}{*}{ Mean } & \multicolumn{3}{|c|}{ Respiration rate six days at $20^{\circ} \mathrm{C}$} & \multirow[t]{2}{*}{ Mean } \\
\hline & $0^{\circ} \mathrm{C}$ & $0.5^{\circ} \mathrm{C}$ & $1.0^{\circ} \mathrm{C}$ & & $0^{\circ} \mathrm{C}$ & $0.5^{\circ} \mathrm{C}$ & $1.0^{\circ} \mathrm{C}$ & & $0^{\circ} \mathrm{C}$ & $0.5^{\circ} \mathrm{C}$ & $1.0^{\circ} \mathrm{C}$ & & $0^{\circ} \mathrm{C}$ & $0.5^{\circ} \mathrm{C}$ & $1.0^{\circ} \mathrm{C}$ & \\
\hline Initial analysis ${ }^{(2)}$ & & 21.8 & & & & 1.33 & & & & 6.86 & & & & 6.86 & & \\
\hline $1.0+2.0$ & $43.0 \mathrm{aA}$ & $44.8 \mathrm{aA}$ & $23.3 \mathrm{bB}$ & 37.0 & $0.26 \mathrm{aA}$ & $0.16 \mathrm{abB}$ & $0.18 \mathrm{aB}$ & 0.20 & $5.36 \mathrm{bAB}$ & $5.54 \mathrm{aA}$ & $4.68 \mathrm{aB}$ & 5.19 & 8.89 & 5.71 & 5.78 & $6.80 \mathrm{a}$ \\
\hline $0.8+2.0$ & $42.5 \mathrm{aA}$ & $29.7 \mathrm{bB}$ & $19.3 \mathrm{bC}$ & 30.5 & $0.25 \mathrm{aA}$ & $0.19 \mathrm{abB}$ & $0.20 \mathrm{aB}$ & 0.21 & 5.91abA & $5.44 \mathrm{aA}$ & $4.51 \mathrm{aB}$ & 5.28 & 8.09 & 6.04 & 6.31 & $6.82 \mathrm{a}$ \\
\hline $0.8+1.5$ & $37.3 \mathrm{aA}$ & $33.8 \mathrm{abAB}$ & 25.4abB & 32.2 & $0.19 \mathrm{bA}$ & $0.15 \mathrm{bA}$ & $0.19 \mathrm{aA}$ & 0.18 & $5.25 \mathrm{bA}$ & $5.24 \mathrm{aA}$ & $4.55 \mathrm{aA}$ & 5.01 & 7.40 & 5.19 & 5.86 & $6.15 \mathrm{a}$ \\
\hline $0.6+1.5$ & $22.1 \mathrm{bA}$ & $25.0 \mathrm{bA}$ & $20.9 \mathrm{bA}$ & 22.7 & $0.16 \mathrm{bAB}$ & $0.14 \mathrm{bB}$ & $0.20 \mathrm{aA}$ & 0.17 & $5.47 \mathrm{bA}$ & $4.05 \mathrm{bB}$ & $5.11 \mathrm{aA}$ & 4.88 & 7.26 & 5.26 & 6.28 & $6.27 \mathrm{a}$ \\
\hline $0.6+1.0$ & 33.3abA & $29.5 \mathrm{bA}$ & $35.1 \mathrm{aA}$ & 32.7 & $0.19 \mathrm{bA}$ & $0.21 \mathrm{aA}$ & $0.17 \mathrm{aA}$ & 0.19 & $6.60 \mathrm{aA}$ & $5.77 \mathrm{aB}$ & $4.88 \mathrm{aC}$ & 5.75 & 7.60 & 7.08 & 6.03 & $6.90 \mathrm{a}$ \\
\hline Mean & 35.7 & 32.6 & 24.8 & - & 0.21 & 0.17 & 0.19 & - & 5.72 & 5.21 & 4.74 & - & $7.85 \mathrm{~A}$ & $5.86 \mathrm{~B}$ & $6.05 \mathrm{~B}$ & \\
\hline
\end{tabular}

${ }^{(1)}$ Means followed by equal letters, lowercase in the columns and uppercase in the lines, do not differ by Tukey's test, at $5 \%$ probability. ${ }^{(2)}$ Initial analysis took place before fruit storage. 
and loss of membrane integrity, resulting in flesh breakdown (Franck et al., 2007).

As to ACC oxidase activity, partial pressures of $\mathrm{O}_{2}$ and $\mathrm{CO}_{2}$ showed contrasting effects at different storage temperatures (Table 2). At $0^{\circ} \mathrm{C}$, the storage of fruit at $0.6 \mathrm{kPa} \mathrm{O}_{2}+1.5 \mathrm{kPa} \mathrm{CO}_{2}$ resulted in a reduction in $\mathrm{ACC}$ activity, although not differing from the conditions with $0.6 \mathrm{kPa} \mathrm{O}_{2}+1.0 \mathrm{kPa} \mathrm{CO}_{2}$. At $0.5^{\circ} \mathrm{C}$, however, the controlled-atmosphere storage with $0.6 \mathrm{kPa} \mathrm{O}_{2}+$ $1.5 \mathrm{kPa} \mathrm{CO}$ caused an increasing effect by inhibiting the ACC oxidase activity, but a difference with $0.8 \mathrm{kPa}$ $\mathrm{O}_{2}+1.5$ or $2.0 \mathrm{kPa} \mathrm{CO}_{2}$ condition was not observed. Thus, when storage temperature was $0.5^{\circ} \mathrm{C}$, a higher $\mathrm{O}_{2}$ partial pressure $(0.8 \mathrm{kPa})$ was required to supply the enzyme activity, due to the lower $\mathrm{O}_{2}$ solubility at higher temperatures (Yearsley et al., 1997). Comparing the temperatures, under conditions where $\mathrm{O}_{2}$ partial pressure were maintained at 0.8 or $1.0 \mathrm{kPa}$, associated to $2.0 \mathrm{kPa} \mathrm{CO}$, the lowest ACC oxidase activity was measured in fruit stored at $1.0^{\circ} \mathrm{C}$. The ACC oxidase, ethylene production rate and flesh breakdown results, showed that, when the storage temperature is increased from 0 to $1.0^{\circ} \mathrm{C}$, the $\mathrm{O}_{2}$ partial pressures must also be raised.

Fruit exposed to $0.6 \mathrm{kPa} \mathrm{O}_{2}$, with the two partial pressures of $\mathrm{CO}_{2}(1.0$ and $1.5 \mathrm{kPa})$ and $0.8 \mathrm{kPa} \mathrm{O}$ $+1.5 \mathrm{kPa} \mathrm{CO}_{2}$ at $0^{\circ} \mathrm{C}$, showed the lowest ethylene production(Table 2). Comparing the tested temperatures to $0^{\circ} \mathrm{C}$, there was a lower ethylene production at 0.5 and $1.0^{\circ} \mathrm{C}$, for conditions of 0.8 and $1.0 \mathrm{kPa} \mathrm{O}_{2}$ combined with $2.0 \mathrm{kPaCO}$. Lower ethylene production was a result of the lower ACC oxidase activity visible in fruit at high temperature. These results may appear incompatible, but excessive reduction of temperature can cause cell damage and a concomitant increase in ethylene production (Knee et al., 1983) resulting in low fruit quality. In agreement with that, the lower occurrence of physiological disorder was observed in fruit stored at $1.0^{\circ} \mathrm{C}$ (Table 1).

By the analysis performed soon after removing fruit from the storage chamber, respiration rate was lower in fruit stored under conditions of higher $\mathrm{CO}_{2}$ partial pressure $(1.5$ and $2.0 \mathrm{kPa})$ at $0^{\circ} \mathrm{C}$ (Table 2). However, at $0.5^{\circ} \mathrm{C}$, only fruit stored at $0.6 \mathrm{kPa} \mathrm{O}_{2}+1.5 \mathrm{kPa}$ $\mathrm{CO}_{2}$ showed lower respiration rate. After a six-day exposure to air at $20^{\circ} \mathrm{C}$, there was no interaction between temperature and controlled-atmosphere storage conditions. Fruit stored at 0.5 and $1.0^{\circ} \mathrm{C}$ showed lower respiration rate than those kept at $0^{\circ} \mathrm{C}$. It has been reported that 'Royal Gala' and 'Galaxy' apples stored in controlled-atmosphere storage exhibited lower respiration at $0.5^{\circ} \mathrm{C}$ in comparison to $-0.5^{\circ} \mathrm{C}$ (Brackmann et al., 2008), thus showing an inverted relationship between temperature (in the range of 0 to $1.0^{\circ} \mathrm{C}$ ) and respiration rate.

\section{Conclusions}

1. The storage of 'Royal Gala' apples under ultralow oxygen (below $0.8 \mathrm{kPa}$ of $\mathrm{O}_{2}$ ) conditions reduces the post-storage quality and increases the occurrence of physiological disorders in fruit.

2. The $1^{\circ} \mathrm{C}$ storage temperature can keep the quality of 'Royal Gala' apples after eight months of controlled-atmosphere storage.

3 . The best ultralow oxygen condition for the storage of 'Royal Gala' apples is $1.0 \mathrm{kPa} \mathrm{O}_{2}$ combined with 2.0 $\mathrm{kPa}$ of $\mathrm{CO}_{2}$ at $1.0^{\circ} \mathrm{C}$.

4. The $\mathrm{O}_{2}$ partial pressures must be increased when storage temperature is higher.

\section{Acknowledgements}

To Conselho Nacional de Desenvolvimento Científico e Tecnológico, Coordenação de Aperfeiçoamento de Pessoal de Nível Superior and Fundação de Amparo à Pesquisa do Estado do Rio Grande do Sul, for financial support.

\section{References}

BRACKMANN, A.; BENEDETTI, M.; STEFFENS, C.A.; MELLO, A.M. de. Efeito da temperatura e condições de atmosfera controlada na armazenagem de maçãs 'Fuji' com incidência de pingo de mel. Revista Brasileira de Agrociência, v.8, p.37-42, 2002.

BRACKMANN, A.; NEUWALD, D.A.; STEFFENS, C.A. Armazenamento de maçã 'Fuji' com incidência de pingo-de-mel. Revista Brasileira de Fruticultura, v.23, p.526-531, 2001.

BRACKMANN, A.; WACLAWOVSKY, A.J.; LUNARDI, R. Qualidade de maçãs cv. Gala armazenadas em diferentes pressões parciais de $\mathrm{O}_{2}$ e $\mathrm{CO}_{2}$. Scientia Agricola, v.57, p.195-198, 2000.

BRACKMANN, A.; WEBER, A.; PINTO, J.A.V.; NEUWALD, D.A.; STEFFENS, C.A. Manutenção da qualidade pós-colheita de maçãs 'Royal Gala' e 'Galaxy' sob armazenamento em atmosfera controlada. Ciência Rural, v.38, p.2478-2484, 2008.

BUFLER, G. Ethylene-promoted conversion of 1-aminocyclopropene-1-carboxylic acid to ethylene in peel of apple at various stages of fruit development. Plant Physiology, v.80, p.539-543, 1986. 
CERETTA, M.; BRACKMANN, A.; PINTO, J.A.V.; LÚCIO, A.D.; ANESE, R.O. Tolerância da maçã 'Gala' a pressões parciais extremas de $\mathrm{O}_{2}$ e $\mathrm{CO}_{2}$ durante o armazenamento. Revista Brasileira de Armazenamento, v.35, p.60-69, 2010.

DELONG, J.M.; PRANGE, R.K.; LEYTE, J.C.; HARRISON, P.A. A new technology that determines low-oxygen thresholds in controlled-atmosphere-stored apples. HortTechnology, v.14, p.262-266, 2004.

FRANCK, C.; LAMMERTYN, J.; HO, Q.T.; VERBOVEN, P.; VERLINDEN, B.; NICOLAI, B.M. Browning disorders in pear fruit. Postharvest Biology and Technology, v.43, p.1-13, 2007.

GRAN, C.D.; BEAUDRY, R.M. Determination of the low oxygen limit for several commercial apple cultivars by respiratory quotient breakpoint. Postharvest Biology and Technology, v.3, p.259-267, 1993.

HIWASA. K.; KINUGASA, Y.; AMANO, S.; HASHIMOTO, A.; NAKANO, R.; INABA, A.; KUBO, Y. Ethylene is required for both the initiation and progression of softening in pear (Pyrus communis L.) fruit. Journal of Experimental Botany, v.54, p.771-779, 2003.

KADER, A.A. (Ed.). Postharvest technology of horticultural crops. $3^{\text {rd }}$ ed. Oakland : University of California, 2002. 535p.

KNEE, M.; LOONEY, N.E.; HATFIELD, S.G.S.; SMITH, S.M. Initiation of rapid ethylene synthesis by apple and pear fruits in relation to storage temperature. Journal of Experimental Botany, v.34, p.1207-1212, 1983.

NEUWALD, D.A. Armazenamento de caqui (Diospyros kaki L.) cultivar Fuyu em atmosfera controlada. 2004. 66p. Dissertação (Mestrado) - Universidade Federal de Santa Maria, Santa Maria.

PEDRESCHI, R.; FRANCK, C.; LAMMERTYN, J.; ERBAN, A.; KOPKA, J.; HERGOT, M.; VERLINDEN, B.; NICOLAI, B. Metabolic profiling of, Conference pears under low oxygen stress. Postharvest Biology and Technology, v.51, p.123-130, 2009.
PRANGE, R.K.; DELONG, J.M.; LEYTE, J.C.; HARRISON, P.A. Oxygen concentration affects chlorophyll fluorescence in chlorophyll-containing fruit and vegetables. Journal of the American Society for Horticultural Science, v.128, p.603-607, 2003.

PRASANNA, V.; PRABHA, T.N.; THARANATHAN, R.N. Fruit ripening phenomena - an overview. Critical Reviews in Food Science and Nutrition, v.47, p.1-19, 2007.

SAQUET, A.A.; STREIF, J. Fermentative metabolism in 'Jonagold' apples under controlled atmosphere storage. European Journal of Horticultural Science, v.73, p.43-46, 2008.

STREIF, J.; SAQUET, A.A.; XUAN, H. CA-related disorders of apples and pears. Acta Horticulturae, v.600, p.223-230, 2003.

WEI, J.; MA F.; SHI,S.; QI, X.; ZHU, X.; YUAN, J. Changes and postharvest regulation of activity and gene expression of enzymes related to cell wall degradation in ripening apple fruit. Postharvest Biology and Technology, v.56, p.147-154, 2010.

WRIGHT,H.;DELONG, J.;HARRISON,P.A.; GUNAWARDENA, A.H.L.A.N.; PRANGE, R. The effect of temperature and other factors on chlorophyll $a$ fluorescence and the lower oxygen limit in apples (Malus domestica). Postharvest Biology and Technology, v.55, p.21-28, 2010.

YANG, S. F.; HOFFMAN, N. E. Ethylene biosynthesis and its regulation in higher plants. Annual Review of Plant Physiology and Plant Molecular Biology, v.35, p.155-189, 1984.

YEARSLEY, C.W.; BANKS, N.H.; GANESH, S. Temperature effects on the internal lower oxygen limits of apple fruit. Postharvest Biology and Technology, v.11, p.73-83, 1997.

ZANELLA, A. Control of apple superficial scald and ripening a comparison between 1-methylcyclopropene and diphenylamine postharvest treatments, initial low oxygen stress and ultra low oxygen storage. Postharvest Biology and Technology, v.27, p.69-78, 2003.

Received on August 1 1', 2011 and accepted on November 7, 2011

Pesq. agropec. bras., Brasília, v.46, n.12, p.1597-1602, dez. 2011 


\section{ERRATA}

No artigo "WEBER, A.; BRACKMANN, A.; ANESE, R. de O.; BOTH, V.; PAVANELLO, E.P. 'Royal Gala' apple quality stored under ultralow oxygen concentration and low temperature conditions. Pesquisa Agropecuária Brasileira, v.46, n.12, p.1597-1602, dez. 2011”, substituir o conteúdo da Tabela 1 pelo seguinte:

Table 1. Occurrence of decay, flesh firmness, mealiness and flesh breakdown in 'Royal Gala' apples, after eight months of storage at different conditions of controlled-atmosphere and temperature and an added exposition for seven days at $20^{\circ} \mathrm{C}^{(1)}$.

\begin{tabular}{|c|c|c|c|c|c|c|c|c|c|c|c|c|c|c|c|c|}
\hline \multirow{2}{*}{$\begin{array}{l}\mathrm{O}_{2}+\mathrm{CO}_{2} \\
(\mathrm{kPa})\end{array}$} & \multicolumn{3}{|c|}{ Decay $(\%)$} & \multirow[t]{2}{*}{ Mean } & \multicolumn{3}{|c|}{ Flesh firmness $(\mathrm{N})$} & \multirow[t]{2}{*}{ Mean } & \multicolumn{3}{|c|}{ Mealiness (\%) } & \multirow[t]{2}{*}{ Mean } & \multicolumn{3}{|c|}{ Flesh breakdown (\%) } & \multirow[t]{2}{*}{ Mean } \\
\hline & $0^{\circ} \mathrm{C}$ & $0.5^{\circ} \mathrm{C}$ & $1.0^{\circ} \mathrm{C}$ & & $0^{\circ} \mathrm{C}$ & $0.5^{\circ} \mathrm{C}$ & $1.0^{\circ} \mathrm{C}$ & & $0^{\circ} \mathrm{C}$ & $0.5^{\circ} \mathrm{C}$ & $1.0^{\circ} \mathrm{C}$ & & $0^{\circ} \mathrm{C}$ & $0.5^{\circ} \mathrm{C}$ & $1.0^{\circ} \mathrm{C}$ & \\
\hline Initial analysis $^{(2)}$ & & 0.0 & & & & 92.8 & & & & 0.0 & & & & 0.0 & & \\
\hline $1.0+2.0$ & 14.0 & 8.8 & 7.5 & $10.1 \mathrm{ab}$ & $76.6 \mathrm{aA}$ & $75.4 \mathrm{aA}$ & $76.4 \mathrm{aA}$ & 76.2 & 26.7 & 30.3 & 16.3 & $24.4 b$ & $32.9 \mathrm{aA}$ & 17.7abB & $5.0 \mathrm{cC}$ & 18.5 \\
\hline $0.8+2.0$ & 10.0 & 12.7 & 7.6 & $10.1 \mathrm{ab}$ & $70.5 \mathrm{bB}$ & $77.5 \mathrm{aA}$ & $77.5 \mathrm{aA}$ & 75.2 & 42.5 & 38.0 & 17.8 & $32.8 \mathrm{a}$ & $36.3 \mathrm{aA}$ & 17.8abB & $8.9 \mathrm{cC}$ & 21.0 \\
\hline $0.8+1.5$ & 7.6 & 8.9 & 6.3 & $7.6 \mathrm{~b}$ & $73.2 \mathrm{abB}$ & $79.3 \mathrm{aA}$ & $75.8 \mathrm{aAB}$ & 76.1 & 34.1 & 29.1 & 20.3 & 27.9ab & $29.0 \mathrm{abA}$ & $13.9 \mathrm{bB}$ & $10.1 \mathrm{bcB}$ & 17.7 \\
\hline $0.6+1.5$ & 10.5 & 14.3 & 16.4 & $13.7 \mathrm{a}$ & $75.1 \mathrm{aA}$ & $77.7 \mathrm{aA}$ & $77.3 \mathrm{aA}$ & 76.7 & 28.6 & 29.4 & 11.4 & $23.2 \mathrm{~b}$ & $27.2 \mathrm{abA}$ & $14.0 \mathrm{bAB}$ & 19.1abB & 20.1 \\
\hline $0.6+1.0$ & 8.7 & 12.5 & 11.4 & $10.9 \mathrm{ab}$ & $73.5 \mathrm{abA}$ & $76.3 \mathrm{aA}$ & $76.8 \mathrm{aA}$ & 75.5 & 27.5 & 32.5 & 17.8 & $25.9 \mathrm{~b}$ & $25.0 \mathrm{bA}$ & $27.5 \mathrm{aA}$ & $22.8 \mathrm{aA}$ & 25.1 \\
\hline Mean & $10.2 \mathrm{~A}$ & $11.4 \mathrm{~A}$ & $9.8 \mathrm{~A}$ & - & 73.8 & 77.2 & 76.8 & - & $31.9 \mathrm{~A}$ & $31.9 \mathrm{~A}$ & $16.7 \mathrm{~B}$ & - & 30.1 & 18.2 & 13.2 & - \\
\hline
\end{tabular}

${ }^{(1)}$ Means followed by equal letters, lowercase in the columns and uppercase in the lines, do not differ by Tukey's test, at $5 \%$ probability. ${ }^{(2)}$ Initial analysis took place before fruit storage.

No artigo "MARIGUELE, K.H.; RESENDE, M.D.V. de; VIANA, J.M.S.; SILVA, F.F. e; SILVA, P.S.L. de; KNOP, F. de C. Métodos de análise de dados longitudinais para o melhoramento genético de pinha. Pesquisa Agropecuária Brasileira, v.46, n.12, p.1657-1664, dez. 2011”, substituir o conteúdo da Tabela 2 pelo seguinte:

Tabela 2. Estimativas dos parâmetros de variância, covariância e correlações, associados aos modelos - autorregressivo de primeira ordem com variâncias heterogêneas (ARH), antedependência estruturada (SAD) e multivariado completo aplicados aos dados originais de número de frutos, em três colheitas de Annona squamosa. Número total de parâmetros dos modelos ARH, SAD e multivariado completo igual a 14, 16 e 18, respectivamente.

\begin{tabular}{|c|c|c|c|c|c|c|c|c|}
\hline \multicolumn{3}{|c|}{ Tratamento (progênie) } & \multicolumn{3}{|c|}{ Parcela } & \multicolumn{3}{|c|}{ Resíduo } \\
\hline Covariância & Variância & Correlação & Covariância & Variância & Correlação & Covariância & Variância & Correlação \\
\hline \multicolumn{9}{|c|}{ Modelo ARH } \\
\hline 2,58 & 8,85 & 0,57 & $0,32 \mathrm{E}-13$ & $0,99 \mathrm{E}-13$ & - & $-4,14$ & 67,18 & $-0,06$ \\
\hline 4,46 & 2,31 & 0,32 & $0,48 \mathrm{E}-6$ & $0,10 \mathrm{E}-13$ & - & $-0,66$ & 74,26 & $-0,01$ \\
\hline 4,06 & 21,94 & 0,57 & $0,15 \mathrm{E}-6$ & 22,56 & - & 5,86 & 51,59 & 0,09 \\
\hline \multirow{2}{*}{\multicolumn{9}{|c|}{$\frac{6.306,44}{\text { Modelo SAD }}$}} \\
\hline & & & & & & & & \\
\hline 4,04 & 8,51 & 0,78 & $-1,71$ & 5,98 & $-0,41$ & 10,28 & 47,64 & 0,26 \\
\hline 3,18 & 3,18 & 0,24 & $-1,76$ & 3,00 & $-0,20$ & 12,09 & 33,56 & 0,16 \\
\hline 2,50 & 20,81 & 0,31 & 3,09 & 12,98 & 0,49 & 15,09 & 116,83 & 0,24 \\
\hline Deviance & \multicolumn{8}{|c|}{$6.137,36$} \\
\hline \multicolumn{9}{|c|}{ Modelo multivariado } \\
\hline 3,35 & 6,31 & 0,90 & $-0,52$ & 1,01 & $-0,76$ & 10,42 & 47,62 & 0,26 \\
\hline 3,32 & 2,19 & 0,35 & $-0,38$ & 0,46 & $-0,27$ & 11,34 & 33,72 & 0,15 \\
\hline 1,25 & 14,30 & 0,22 & 0,72 & 1,99 & 0,75 & 14,74 & 116,30 & 0,24 \\
\hline Deviance & & & & $6.136,7$ & & & & \\
\hline
\end{tabular}




\section{ERRATA}

In the paper "WEBER, A.; BRACKMANN, A.; ANESE, R. de O.; BOTH, V.; PAVANELLO, E.P. 'Royal Gala' apple quality stored under ultralow oxygen concentration and low temperature conditions. Pesquisa Agropecuária Brasileira, v.46, n.12, p.1597-1602, Dez. 2011”, replace the content of Table 1 by the following:

Table 1. Occurrence of decay, flesh firmness, mealiness and flesh breakdown in 'Royal Gala' apples, after eight months of storage at different conditions of controlled-atmosphere and temperature and an added exposition for seven days at $20^{\circ} \mathrm{C}^{(1)}$.

\begin{tabular}{|c|c|c|c|c|c|c|c|c|c|c|c|c|c|c|c|c|}
\hline \multirow{2}{*}{$\begin{array}{l}\mathrm{O}_{2}+\mathrm{CO}_{2} \\
(\mathrm{kPa})\end{array}$} & \multicolumn{3}{|c|}{ Decay $(\%)$} & \multirow[t]{2}{*}{ Mean } & \multicolumn{3}{|c|}{ Flesh firmness $(\mathrm{N})$} & \multirow[t]{2}{*}{ Mean } & \multicolumn{3}{|c|}{ Mealiness (\%) } & \multirow[t]{2}{*}{ Mean } & \multicolumn{3}{|c|}{ Flesh breakdown (\%) } & \multirow[t]{2}{*}{ Mean } \\
\hline & $0^{\circ} \mathrm{C}$ & $0.5^{\circ} \mathrm{C}$ & $1.0^{\circ} \mathrm{C}$ & & $0^{\circ} \mathrm{C}$ & $0.5^{\circ} \mathrm{C}$ & $1.0^{\circ} \mathrm{C}$ & & $0^{\circ} \mathrm{C}$ & $0.5^{\circ} \mathrm{C}$ & $1.0^{\circ} \mathrm{C}$ & & $0^{\circ} \mathrm{C}$ & $0.5^{\circ} \mathrm{C}$ & $1.0^{\circ} \mathrm{C}$ & \\
\hline Initial analysis $^{(2)}$ & & 0.0 & & & & 92.8 & & & & 0.0 & & & & 0.0 & & \\
\hline $1.0+2.0$ & 14.0 & 8.8 & 7.5 & $10.1 \mathrm{ab}$ & $76.6 \mathrm{aA}$ & $75.4 \mathrm{aA}$ & $76.4 \mathrm{aA}$ & 76.2 & 26.7 & 30.3 & 16.3 & $24.4 b$ & $32.9 \mathrm{aA}$ & 17.7abB & $5.0 \mathrm{cC}$ & 18.5 \\
\hline $0.8+2.0$ & 10.0 & 12.7 & 7.6 & $10.1 \mathrm{ab}$ & $70.5 \mathrm{bB}$ & $77.5 \mathrm{aA}$ & $77.5 \mathrm{aA}$ & 75.2 & 42.5 & 38.0 & 17.8 & $32.8 \mathrm{a}$ & $36.3 \mathrm{aA}$ & $17.8 \mathrm{abB}$ & $8.9 \mathrm{cC}$ & 21.0 \\
\hline $0.8+1.5$ & 7.6 & 8.9 & 6.3 & $7.6 \mathrm{~b}$ & $73.2 \mathrm{abB}$ & $79.3 \mathrm{aA}$ & $75.8 \mathrm{aAB}$ & 76.1 & 34.1 & 29.1 & 20.3 & $27.9 \mathrm{ab}$ & 29.0abA & $13.9 \mathrm{bB}$ & $10.1 \mathrm{bcB}$ & 17.7 \\
\hline $0.6+1.5$ & 10.5 & 14.3 & 16.4 & $13.7 \mathrm{a}$ & $75.1 \mathrm{aA}$ & $77.7 \mathrm{aA}$ & $77.3 \mathrm{aA}$ & 76.7 & 28.6 & 29.4 & 11.4 & $23.2 \mathrm{~b}$ & $27.2 \mathrm{abA}$ & $14.0 \mathrm{bAB}$ & 19.1abB & 20.1 \\
\hline $0.6+1.0$ & 8.7 & 12.5 & 11.4 & $10.9 \mathrm{ab}$ & $73.5 \mathrm{abA}$ & $76.3 \mathrm{aA}$ & $76.8 \mathrm{aA}$ & 75.5 & 27.5 & 32.5 & 17.8 & $25.9 \mathrm{~b}$ & $25.0 \mathrm{bA}$ & $27.5 \mathrm{aA}$ & $22.8 \mathrm{aA}$ & 25.1 \\
\hline Mean & $10.2 \mathrm{~A}$ & $11.4 \mathrm{~A}$ & $9.8 \mathrm{~A}$ & - & 73.8 & 77.2 & 76.8 & - & $31.9 \mathrm{~A}$ & $31.9 \mathrm{~A}$ & $16.7 \mathrm{~B}$ & - & 30.1 & 18.2 & 13.2 & - \\
\hline
\end{tabular}

${ }^{(1)}$ Means followed by equal letters, lowercase in the columns and uppercase in the lines, do not differ by Tukey's test, at $5 \%$ probability. ${ }^{(2)}$ Initial analysis took place before fruit storage.

In the paper "MARIGUELE, K.H.; RESENDE, M.D.V. de; VIANA, J.M.S.; SILVA, F.F. e; SILVA, P.S.L. de; KNOP, F. de C. Métodos de análise de dados longitudinais para o melhoramento genético de pinha. Pesquisa Agropecuária Brasileira, v.46, n.12, p.1657-1664, Dez. 2011”, replace the content of Table 2 by the following:

Tabela 2. Estimativas dos parâmetros de variância, covariância e correlações, associados aos modelos - autorregressivo de primeira ordem com variâncias heterogêneas (ARH), antedependência estruturada (SAD) e multivariado completo aplicados aos dados originais de número de frutos, em três colheitas de Annona squamosa. Número total de parâmetros dos modelos ARH, SAD e multivariado completo igual a 14, 16 e 18, respectivamente.

\begin{tabular}{|c|c|c|c|c|c|c|c|c|}
\hline \multicolumn{3}{|c|}{ Tratamento (progênie) } & \multicolumn{3}{|c|}{ Parcela } & \multicolumn{3}{|c|}{ Resíduo } \\
\hline Covariância & Variância & Correlação & Covariância & Variância & Correlação & Covariância & Variância & Correlação \\
\hline \multicolumn{9}{|c|}{ Modelo ARH } \\
\hline 2,58 & 8,85 & 0,57 & $0,32 \mathrm{E}-13$ & 0,99E-13 & - & $-4,14$ & 67,18 & $-0,06$ \\
\hline 4,46 & 2,31 & 0,32 & $0,48 \mathrm{E}-6$ & $0,10 \mathrm{E}-13$ & - & $-0,66$ & 74,26 & $-0,01$ \\
\hline 4,06 & 21,94 & 0,57 & $0,15 \mathrm{E}-6$ & 22,56 & - & 5,86 & 51,59 & 0,09 \\
\hline \multirow{2}{*}{\multicolumn{9}{|c|}{$\frac{6.306,44}{\text { Modelo SAD }}$}} \\
\hline & & & & & & & & \\
\hline 4,04 & 8,51 & 0,78 & $-1,71$ & 5,98 & $-0,41$ & 10,28 & 47,64 & 0,26 \\
\hline 3,18 & 3,18 & 0,24 & $-1,76$ & 3,00 & $-0,20$ & 12,09 & 33,56 & 0,16 \\
\hline 2,50 & 20,81 & 0,31 & 3,09 & 12,98 & 0,49 & 15,09 & 116,83 & 0,24 \\
\hline Deviance & \multicolumn{8}{|c|}{$6.137,36$} \\
\hline \multicolumn{9}{|c|}{ Modelo multivariado } \\
\hline 3,35 & 6,31 & 0,90 & $-0,52$ & 1,01 & $-0,76$ & 10,42 & 47,62 & 0,26 \\
\hline 3,32 & 2,19 & 0,35 & $-0,38$ & 0,46 & $-0,27$ & 11,34 & 33,72 & 0,15 \\
\hline 1,25 & 14,30 & 0,22 & 0,72 & 1,99 & 0,75 & 14,74 & 116,30 & 0,24 \\
\hline Deviance & & & & $6.136,76$ & & & & \\
\hline
\end{tabular}

